Bennett, I. L., Freeman, H. C., Mitchell, G. L., and Cooper, M. N. (1953). Medicine, 32, 431.

Berryman, D. B., and George, W. H. S. (1960). Archives of Surgery, 80, 482. Bossak, E. T., and Joelson, R. H. (1956). Archives of Internal Medicine, 97,

201. ., Birath, K., and Brown, B. (1969). Clinica Chimica Acta, 26, 437. Ceska, M., Birath, K., and Brown, B. (1969). Clinic
Finn, R., and Cope, S. (1963). Diabetes, 12, 141.

Finn, R., and Cope, S. (1963). Diabetes, 12, 141. Clinical Chemistry, 17, 423.

Fridhandler, L., Berk, J. E., and Ueda, M. (1971). Clinical Chemistry, 17, 423. Medicine, 67, 819.

Medicine, 67, 819.
Hughes, P. D. (1961). British Fournal of Surgery, 49, 90.

Janowitz, H. D., and Dreiling, D. A. (1959). American fournal of Medicine, 27,924 .

Jones, C. A. (1955). Archives of Internal Medicine, 96, 332.

King, E. J. (1951). In Micro-Analysis in Medical Biochemistry, 2nd edn., p. 77. London, Churchill.

McGeachin, R. L., Gleason, J. R., and Adams, M. R. (1958). Archives of Biochemistry and Biophysics, 75, 403.
McGeachin, R. L., and Hargan, L. A. (1956). Proceedings of the Society for Experimental Biology and Medicine, 87, 79.

Malins, J. (1968). In Clinical Diabetes Mellitus, p. 116. London, Eyre and

Spottiswoode.
Pollock, A. V. (1959). British Medical fournal, 1, 6.

Rajasinghan, R., Bell, J. L., and Baron, D. N. (1971). Enzyme, 12, 180.

Reid, E., and Myers, V. C. (1932). Fournal of Biological Chemistry, 99, 607.

Shihabi, Z. K., and Bishop, C. (1971). Clinical Chemistry, 17, 1150. Tranquada, R. E., Grant, W. J., and Peterson, C. R. (1966). Archives of $\frac{\mathbb{Q}}{\complement}$
Internal Medicine, 117, 192.

Trapnell, J. E. (1966). Annals of the Royal College of Surgeons of England, 38, $\overrightarrow{\overrightarrow{\vec{F}}}$ 265.

Tully, G. T., and Lowenthal, J. J. (1958). Annals of Internal Medicine, 48, 310

Velez-Garcia, E., Hardy, P., Dioso, M., and Perkoff, G. T. (1966). Fournal of Laboratory and Clinical Medicine, 68, 637.

Warren, S., and LeCompte, P. M. (1952). In The Pathology of Diabetes Mellitus, 3rd edn., p. 111. Philadelphia, Lea and Febiger.

\title{
Treatment of Hypothyroidism: A Reappraisal of Thyroxine Therapy
}

\author{
DAVID EVERED, E. T. YOUNG, \\ REGINALD HALL \\ B. J. ORMSTON, RUTH MENZIES, \\ P. A. SMITH,
}

British Medical fournal, 1973, 3, 131-134

now used almost exclusively in the management of patients with hypothyroidism. The dose recommended by the major textbooks of medicine (Selenkow and Ingbar, 1970; Stanbury, 1967; Strong, 1968) and endocrinology (Ingbar and Woeber, 1967; Hall et al., 1969; Means et al., 1963) lies between 0.2 mg and $0.4 \mathrm{mg}$ daily, and there is general agreement that $0.3 \mathrm{mg}$ daily is the average replacement dose. It is well known that the serum thyroxine concentration is raised on this dose and in the past it has been assumed that since the patient was receiving only $\mathrm{T}-4$, and no replacement with the metabolically more potent triiodo-L-thyronine ( $\mathrm{T}-3$ ), that this was essential to maintain the euthyroid state (Ingbar and Woeber, 1968). Cotton et al. (1971), however, found that the serum thyroidstimulating hormone (TSH) concentration can be restored to normal with much smaller doses of T-4. It has also recently been shown that there is considerable extrathyroidal conversion of T-4 to T-3 (Pittman et al., 1971; Sterling et al., 1970) and that raised serum T-3 levels are found in athyreotic subjects receiving T-4 only (Braverman et al., 1970). These findings raise the possibility that many subjects on replacement therapy with T-4 are mildly hyperthyroid but this state escapes detection in view of the insensitive methods available for the clinical assessment of thyroid status (Larsen, 1972). Goolden and his colleagues (1971) provided some support for this view by showing that the red cell sodium concentration which is increased in hyperthyroidism is also raised in subjects receiving $0.3 \mathrm{mg}$ T-4 daily. The availability of a wide range of precise diagnostic techniques has made it possible to test this hypothesis and to study the thyroid hormone requirements of a group of unselected patients with hypothyroidism.

\section{Patients, Materials, and Methods}

Twenty-two consecutive patients with untreated symptomatic hypothyroidism attending an endocrine clinic were studied. The diagnosis of symptomatic hypothyroidism was accepted in all patients who presented with symptoms consistent with hypothyroidism and were found to have a raised serum TSH concentration (Evered et al., 1973). Seventeen of the patients had developed hypothyroidism spontaneously, three after ${ }^{131}$ I therapy and two after partial thyroidectomy for hyperthyroidism. None of the subjects had overt ischaemic heart disease.

\begin{abstract}
Introduction
It is generally accepted that all patients with symptomatic hypothyroidism require treatment, and L-thyroxine ( $T-4)$ is

\footnotetext{
Department of Medicine and Clinical Biochemistry, University of Newcastle upon Tyne, Newcastle upon Tyne NE1 4LP

DAVID EVERED, M.D., M.R.C.P., Wellcome Senior Research Fellow in Clinical Science and Honorary Lecturer in Medicine

B. J. ORMSTON, M.B., B.S., Research Registrar (Present appointment: Medical Registrar, The General Infirmary, Leeds)

RUTH MENZIES, B.SC., Biochemist

P. A. SMITH, B.SC., PH.D., Hospital Biochemist

REGINALD HALL, M.D., F.R.C.P., Professor of Medicine
}

E. T. YOUNG, M.B., M.R.C.P., Consultant Physician
\end{abstract}




\section{INITIAL ASSESSMENT}

A clinical assessment was carried out on each subject by one of three observers (D.E., E.T.Y., B.J.O.). The symptoms and signs were scored using a diagnostic index for hypothyroidism (Billewicz et al., 1969). The index was used only as an aid to follow the symptomatic progress of each patient. The absolute numerical value before therapy was not used to establish the initial diagnosis.

Investigation of Thyroid Function.-The protein bound iodine (P.B.I.) (Technicon AutoAnalyzer) and T-3 Sephadex uptake (Radio-Chemical Centre, Amersham) (Clark and Brown, 1970 a) were measured on all subjects. The free thyroxine index was computed from these two measurements (Clark and Brown, 1970 b). Serum T-3 concentration was estimated by radioimmunoassay on unextracted serum (Hesch and Evered, 1973).

Investigation of Peripheral Tissue Function.-Fasting serum cholesterol was measured by Technicon AutoAnalyzer using an isopropanol extraction (Block et al., 1966). Fasting serum triglyceride concentration was measured by the technique of Fletcher (1968). The duration of the ankle tendon reflex was measured with a Cranlea reflexometer. A standard 12-lead electrocardiogram was carried out on all subjects with an Elema-Schönander 3-channel electrocardiograph. All electrocardiograms were carefully standardized, and changes during treatment were assessed by comparing the sum of the maximum deflection in each lead.

Investigation of Hypothalamic-Pituitary Function.-Serum TSH was measured by a double antibody radioimmunoassay technique (Hall et al., 1971). The overall normal range was established on 236 subjects (aged between 18 and 85 ) drawn at random from a normal population. The values in men were: mean $1.7 \mu \mathrm{U} / \mathrm{ml}$, median $1.7 \mu \mathrm{U} / \mathrm{ml}$, normal range (95\% confidence limits) $<0.5-3.5 \mu \mathrm{U} / \mathrm{ml}$; and in women: mean $1.7 \mu \mathrm{U} / \mathrm{ml}$, median $1.6 \mu \mathrm{U} / \mathrm{ml}$, normal range (95\% confidence limits) $<0.5-3.75 \mu \mathrm{U} / \mathrm{ml}$. The TSH responses to a $200 \mu \mathrm{g}$ dose of intravenous thyrotrophin-releasing hormone (TRH) was measured in all subjects (Ormston et al., 1971).

\section{PLAN OF TREATMENT AND SUBSEQUENT STUDIES}

All subjects were treated with T-4. Those under the age of 50 were started on $0.1 \mathrm{mg} T-4$ daily and those over this age were started on $0.05 \mathrm{mg}$ daily. The dose of T-4 in each subject was increased by $0.05 \mathrm{mg}$ increments until the patients were asymptomatic and had a normal TSH response to TRH. The dose was increased in each subject at six-weekly intervalsit having been shown by prior experiment that the maximum suppression of TSH by each dose increment of T-4 was achieved in this time.
A clinical assessment of each subject was carried out at the time of each increase of dose and also all the other initial measurements were repeated at each clinic visit, with the exception of one elderly patient in whom later TRH tests were not carried out, but basal TSH estimations and all other investigations were performed. The assessments were also carried out after six weeks on the final dose of T-4 except in four subjects in whom a 12-week period elapsed before final assessment was possible. The subjects were investigated fasting and were instructed not to take the dose of $\mathrm{T}-4$ before the clinic visit.

\section{Results}

All the subjects had clinical and biochemical evidence of hypothyroidism (Evered et al., 1973). It was found that the dose of T-4 required to suppress serum TSH concentration to normal lay between $0.1 \mathrm{mg}$ and $0.2 \mathrm{mg}$, and on these doses the patients studied became asymptomatic. A normal serum TSH concentration was achieved by $0.1 \mathrm{mg} \mathrm{T}-4$ in 13 patients, $0.15 \mathrm{mg}$ in six patients, and $0.2 \mathrm{mg}$ in the remaining three patients. The TSH responses to TRH are shown in the chart. It will be seen

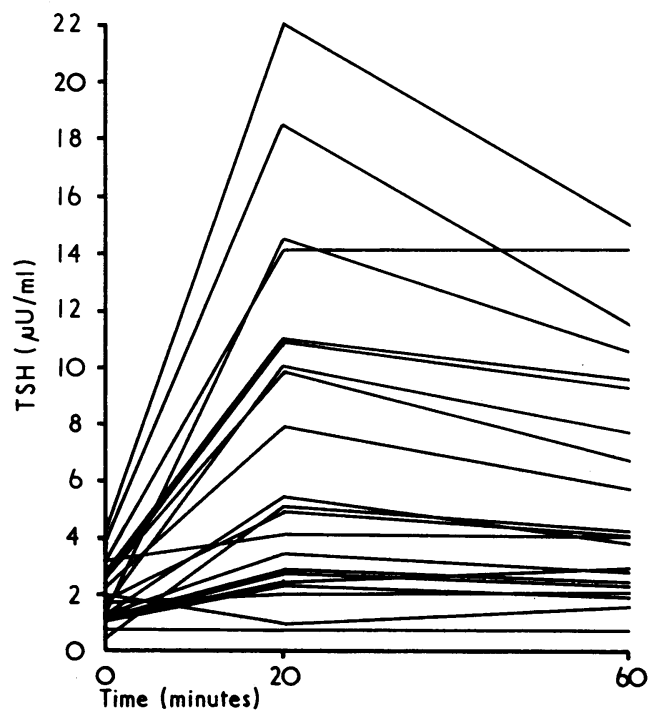

TSH responses to $200 \mu \mathrm{g}$ intravenous TRH in subjects stabilized on $\mathrm{T}-4$.

that on these doses nine subjects had a normal response, nine had an impaired response, and three had an absent response. Absent or impaired responses were not seen with any greater frequency in those requiring 0.15 and $0.2 \mathrm{mg} \mathrm{T}-4$ than in those requiring $0.1 \mathrm{mg}$. In all subjects the TRH response at one dose

Clinical and Biochemical Assessment in Patients before Treatment (Pre) and when Stabilized on Thyroxine (Post). (Values in Age and Sex Matched Controls Given for Comparison)

\begin{tabular}{|c|c|c|c|c|c|c|c|c|c|c|c|c|c|c|c|c|c|c|}
\hline \multirow{3}{*}{ Controls: } & \multirow{2}{*}{\multicolumn{2}{|c|}{$\frac{\begin{array}{c}\text { Clinical } \\
\text { Assessment }\end{array}}{-33(+6 \text { to- }-53)}$}} & \multirow{2}{*}{\multicolumn{2}{|c|}{$\frac{\begin{array}{c}\text { P.B.I. } \\
(\mu \mathrm{g} / 100 \mathrm{ml})\end{array}}{5.4 \pm 1.5}$}} & \multirow{2}{*}{\multicolumn{2}{|c|}{$\begin{array}{l}\text { Thy/opac-3 } \\
1.09 \pm 0.07\end{array}$}} & \multirow{2}{*}{\multicolumn{2}{|c|}{$\frac{c}{\begin{array}{c}\text { Free } \\
\text { Thyroxine } \\
\text { Index }\end{array}}$}} & \multirow{2}{*}{\multicolumn{2}{|c|}{$\frac{\begin{array}{c}\text { Serum } \mathrm{T}-3 \\
(\mathrm{ng} / \mathrm{ml})\end{array}}{1.26 \pm 0.23}$}} & \multirow{2}{*}{\multicolumn{2}{|c|}{$\frac{\underset{(\mu U / \mathrm{ml})}{\operatorname{Serum}} \mathrm{TSH}}{2.5 \pm 0.7}$}} & \multirow{2}{*}{\multicolumn{2}{|c|}{$\begin{array}{c}\begin{array}{c}\text { Cholesterol } \\
(\mathrm{mg} / 100 \mathrm{ml})\end{array} \\
231 \pm 48\end{array}$}} & \multirow{2}{*}{\multicolumn{2}{|c|}{$\begin{array}{c}\begin{array}{c}\text { Triglyceride } \\
(\mathrm{mg} / 100 \mathrm{ml})\end{array} \\
103 \pm 52\end{array}$}} & \multirow{2}{*}{\multicolumn{2}{|c|}{$\begin{array}{c}\begin{array}{c}\text { Ankle Tendon } \\
\text { Refiex } \\
(\mathrm{m} \mathrm{sec})\end{array} \\
290 \pm 25\end{array}$}} \\
\hline & & & & & & & & & & & & & & & & & & \\
\hline & Pre & Post & Pre & Post & Pre & Post & Pre & Post & Pre & Post & Pre & Post & Pre & Post & Pre & Post & Pre & Post \\
\hline $\begin{array}{l}\text { Group 1 (0.1 } \\
\text { mg T-4) }\end{array}$ & +2 & -24 & $\begin{array}{r}4.4 \\
\pm 1 \cdot 22 \\
\end{array}$ & $\begin{array}{r}5.7 \\
\pm 1.6\end{array}$ & $\begin{array}{r}1.09 \\
\pm 0.07 \\
\end{array}$ & $\begin{array}{r}1.03 \\
\pm 0.04 \\
\end{array}$ & \begin{tabular}{|c|}
$4 \cdot 0$ \\
$\pm 1 \cdot 08$ \\
\end{tabular} & $\begin{array}{r}5.6 \\
\pm 1.6\end{array}$ & $\begin{array}{r}0.81 \\
+0.33\end{array}$ & $\begin{array}{r}1.83 \\
\pm 0.42 \\
\end{array}$ & $\begin{array}{r}27 \cdot 9 \\
+25 \cdot 9 \\
\end{array}$ & $\begin{array}{r}2.2 \\
\pm 1.0\end{array}$ & $\begin{array}{r}265 \\
+\quad 74 \\
\end{array}$ & $\begin{array}{r}238 \\
+\quad 71\end{array}$ & $\begin{array}{r}131 \\
\pm \quad 60\end{array}$ & $\begin{array}{r}140 \\
\pm \quad 27\end{array}$ & $\begin{array}{r}345 \\
\pm \quad 46 \\
\end{array}$ & $\begin{array}{r}310 \\
\pm \quad 46\end{array}$ \\
\hline $\begin{array}{l}\text { Group } 2(0.15 \\
\text { and } 0.2 \mathrm{mg} \mathrm{T}-4)\end{array}$ & +30 & -30 & \begin{tabular}{|r|}
3.4 \\
\pm 1.24 \\
\end{tabular} & $\begin{array}{r}6.6 \\
\pm 1.4\end{array}$ & $\begin{array}{r}1.23 \\
\pm 0.15 \\
\end{array}$ & $\begin{array}{r}1.05 \\
\pm 0.06 \\
\end{array}$ & $\begin{array}{r}2.9 \\
\pm 1.33 \\
\end{array}$ & $\begin{array}{r}6.3 \\
\pm 1.1 \\
\end{array}$ & $\begin{array}{r}0.60 \\
+0.50\end{array}$ & $\begin{array}{r}1.84 \\
+0.53\end{array}$ & $\begin{array}{r}81 \cdot 0 \\
+49 \\
\end{array}$ & $\begin{array}{r}1.9 \\
\pm 1.1\end{array}$ & $\begin{array}{r}358 \\
\pm 129 \\
\end{array}$ & $\begin{array}{r}250 \\
\pm \quad 41\end{array}$ & $\begin{array}{r}210 \\
+\quad 89\end{array}$ & $\begin{array}{r}150 \\
\pm \quad 53\end{array}$ & $\begin{array}{r}436 \\
\pm 151 \\
\end{array}$ & $\begin{array}{r}309 \\
\pm \quad 46\end{array}$ \\
\hline $\begin{array}{c}\text { Comparison of } \\
\text { groups } 1 \text { and } 2\end{array}$ & $\begin{array}{l}0.05>P \\
>0.025\end{array}$ & N.S. & $\begin{array}{l}0.05>P \\
>0.025\end{array}$ & N.S. & $\overline{P<0.01}$ & N.S. & $\begin{array}{l}0.05>P \\
>0.025\end{array}$ & N.S. & N.S. & N.S. & $P<0.01$ & N.S. & $\begin{array}{l}0.05>\mathrm{P} \\
>0.025\end{array}$ & N.S. & $\begin{array}{l}0.025> \\
P>0.01\end{array}$ & N.S. & $\begin{array}{l}0.05>\mathrm{P} \\
>0.025\end{array}$ & N.S. \\
\hline
\end{tabular}


increment below the final dose was in the hypothyroid range. The dose was increased by $0.05 \mathrm{mg}$ daily above the final dose in five subjects and at this dosage none showed response to TRH.

The results from the study were analysed by placing the subjects into two groups in view of the small numbers involved. Those subjects who were stabilized on a final dose of $0.1 \mathrm{mg}$ T-4 (13 subjects-group 1) were compared with those stabilized on a higher dose (nine subjects-group 2). The results are summarized in the table.

Clinical Assessment.-The subjects who were stabilized in group 1 generally had diagnostic scores (Billewicz et al., 1969) in the equivocal range, whereas those in group 2 had diagnostic scores in the overtly hypothyroid range. The difference between the two groups was significant at the $5 \%$ level. It was also noted when using previously established diagnostic criteria (Evered et al., 1973) that in group 1 five subjects had mild hypothyroidism and eight had overt disease, whereas only one subject in group 2 had mild hypothyroidism. All patients became asymptomatic with treatment and the diagnostic scores fell within the normal range. The values recorded in the two groups on treatment were very similar.

\section{CIRCULATING THYROID HORMONE CONCENTRATIONS}

The P.B.I. and free thyroxine index were significantly lower in those subjects requiring a larger dose of $T-4$ than in those stabilized on a smaller dose. The T-3 Sephadex uptake was similarly noted to be significantly higher in those subjects with the greatest T-4 requirements. The values recorded in these subjects on treatment all fell within the conventionally accepted normal range, and similar values were recorded in these two groups. The serum T-3 concentrations in the subjects studied ranged from low values to some which lay in the lower part of the normal range. The initial values in those requiring the larger doses of T-4 were slightly lower than in those requiring $0.1 \mathrm{mg}$ daily, but this difference was not statistically significant. It was noted that the mean serum $T-3$ value in the patients when stabilized on treatment was marginally raised-individual values ranging from 1.0 to $2.3 \mathrm{ng} / \mathrm{ml}$ (means $1.83 \mathrm{ng} / \mathrm{ml}$ in group $1 ; 1.84 \mathrm{ng} / \mathrm{ml}$ in group 2). It was noted that the high $\mathrm{T}-3$ values in the patients who were stabilized on T-4 were all in the group who were studied six weeks after being established on the final dose. The four subjects who had their final assessment at 12 weeks had final T-3 values which were entirely normal (1.42, $1 \cdot 10,1 \cdot 27$, and $1.35 \mathrm{ng} / \mathrm{ml}$ ).

The serum TSH concentration showed a mean value before treatment in those stabilized on $0.1 \mathrm{mg} \mathrm{T}-4$ of $27.9 \mu \mathrm{U} / \mathrm{ml}$ and in those requiring a larger dose of $\mathrm{T}-4$ the mean value was significantly higher $-81.0 \mu \mathrm{U} / \mathrm{ml}$. The basal values, of course, in both groups fell to within the normal range on treatment since this was used as one of the criteria of adequacy of treatment.

Serum cholesterol concentrations were found to be marginally raised in group 1 and much higher in group 2, and though there was a wide scatter in each group this difference was statistically significant. Similar differences in serum triglyceride concentration were seen in the two groups before treatment-the mean value in group 1 lying within the normal range and in group 2 being substantially raised. The mean values after treatment fell within the normal range. One feature of the serum triglyceride concentrations in group 1 was that though some subjects had raised values which fell on treatment four had rather low values, $70-75 \mathrm{mg} / 100 \mathrm{ml}$, which rose on treatment to values between 110 and $140 \mathrm{mg} / 100 \mathrm{ml}$. One subject who also had Gaucher's disease was excluded from the analysis of serum lipid results since she had the systemic hyperlipidaemia which sometimes accompanies this condition. The serum cholesterol was $330 \mathrm{mg} / 100 \mathrm{ml}$ and triglyceride $300 \mathrm{mg} / 100 \mathrm{ml}$ before treatment for hypothyroidism and these values did not change with treatment of her hypothyroidism.

The duration of ankle tendon reflex was marginally prolonged in group 1 and significantly more abnormal in group 2 . It fell to normal in both groups on treatment. Assessment of voltage changes on the electrocardiogram yielded little information. The E.C.G. was obviously subjectively abnormal in only two subjects before treatment (one from each group) and in these two a significant rise in voltage was noted $(+24 \mathrm{~mm}$ and $+31 \mathrm{~mm})$. No significant change was noted in the remaining patients.

The results are fully summarized in the table, which also shows values obtained in a group of normal controls who were matched for age and sex with the hypothyroid patients.

\section{Discussion}

The clinical, biochemical, and tissue responses to thyroxine medication have been examined in 22 subjects with symptomatic hypothyroidism. The diagnosis of symptomatic hypothyroidism was accepted in all subjec ${ }^{+} s$ with a raised serum TSH concentration and symptoms consistent with hypothyroidism. The limitations of this definition in subjects with mild hypothyroidism are recognized and have previously been discussed in detail (Evered et al., 1973). The adequacy of replacement therapy was assessed by two major criteria-the relief of symptoms and the reduction of the serum TSH concentration into the normal range. The symptoms of all the patients were relieved on much smaller doses of T-4 than have been conventionally used in the past - and this was shown by a significant reduction in their symptom score on a diagnostic index (Billewicz et al., 1969). The scores on therapy were indistinguishable from those of a group of age and sex matched controls who were euthyroid. It has been proposed (Evered and Hall, 1972) that an increased serum TSH concentration is a sensitive index of any deviation from the optimum level of circulating thyroid hormone and this has been confirmed experimentally (Evered et al., 1973), and thus the suppression of serum TSH concentration has been used as the major biochemical criterion of adequacy of therapy. It was clearly shown that any further increase in T-4 dosage above the minimum quantity necessary to reduce serum TSH concentration resulted in an abolition of the TSH response to exogenous TRH suggesting that any further increase in dose produced a degree of hyperthyroidism. It was not possible to adjust the dose of T-4 finely enough to establish an entirely normal TSH response to TRH in all subjects, but a normal or impaired response was achieved in 18 of the 21 subjects in whom serial TRH tests were performed. These findings confirm and extend those of Cotton et al. (1971) who merely followed the serum TSH concentration back to normal. They also strongly support the view that conventional replacement therapy often induces a mild state of hyperthyroidism which cannot be detected by clinical methods alone.

It was noteworthy that the indirect estimations of serum thyroxine concentration on the final doses of $T-4$ gave values within the normal range, which were identical with those of a group of control subjects. The serum T-3 concentrations in these patients on therapy were marginally raised, and the explanation for this finding is not evident. It is now established that the serum T-3 falls later than T-4 in subjects with hypothyroidism (Larsen, 1972) and some subjects with early thyroid failure have raised levels of serum T-3 concentration (Bellabarba et al., 1972; Evered et al., 1973). It is not clear at present whether this represents an increased thyroidal secretion of $T-3$ or increased extrathyroidal conversion of $T-4$ to $T-3$. If the latter process plays a major part in this compensatory mechanism then the raised levels of T-3 concentration after only six weeks on the final dose of T-4 can perhaps be accounted for on this basis. It is noteworthy that normal T-3 values were found in all four subjects who were assessed at 12 weeks rather than six weeks. This finding could be adduced as an argument in favour of an increased extrathyroidal conversion of T-4 to T-3 playing a part in the adaptation to developing hypothyroidism. Repeat estimations of serum T-3 after a longer period on T-4 might, 
therefore, show normal serum T-3 concentrations in all these subjects - and some preliminary studies suggest that this may well be the case. It is clear, in any event, that replacement with T-3 is not required, nor is there anything to recommend replacement with tablets containing mixtures of $T-4$ and $T-3$ as has been previously suggested (Taylor et al., 1970). It is also clear that a raised P.B.I. or serum thyroxine concentration is not a prerequisite for effective replacement therapy.

It has been found that after stabilization on $T-4$ the serum lipid concentrations fell substantially in most subjects, and when the patients were maintained on a dose of T-4 which rendered them clinically and biochemically euthyroid then the serum cholesterol and triglyceride concentrations were very similar to those recorded in a group of control subjects. The prevalence of abnormal values on therapy was similar to that in the control group. The raised levels of serum triglyceride concentration after treatment is unexplained and has not been reported previously. The duration of the ankle tendon reflex fell in association with the other changes to a value similar to that seen in the controls.

A statistical analysis of the clinical and biochemical data collected before the institution of therapy shows very clearly that those subjects who were stabilized on the smaller doses of T-4 (0.1 mg daily) had a minor degree of thyroid failure compared with those subjects who required larger doses. Adequate replacement therapy as judged by the clinical and biochemical criteria used in this study results in the two groups being indistinguishable in respect of all parameters of thyroid function examined, and, with the exception of serum T-3 concentrations, the subjects were also indistinguishable from a euthyroid control group at this stage. It remains to be established whether those subjects stabilized on the smaller doses of thyroxine will require larger quantities of thyroid hormone as time progresses. Clearly a long-term follow-up study would be of interest.

The results of this study suggest that many subjects have received excessive doses of T-4 in the past, inducing a state of mild hyperthyroidism which is generally not clinically apparent. These findings confirm the isolated findings which have been reported previously (Braverman et al., 1970; Cotton et al., 1971; Goolden et al., 1971) which suggested that conventional doses of T-4 for replacement therapy were often excessive. It is not possible to be certain whether this state of mild hyperthyroidism is detrimental to the patient-but the disadvantages of untreated mild hyperthyroidism, particularly in relation to the skeleton and the cardiovascular system in the elderly, are well known. There would, therefore, seem to be a good prima facie case for establishing patients with hypothyroidism on the optimal dose of T-4.
It is, of course, not possible to investigate all patients with hypothyroidism in such detail. It is, however, possible to stabilize all patients on thyroid hormone replacement therapy by increasing the dose of T-4 until the serum TSH concentration falls within the normal range. Experience with this study has shown that patients' symptoms are abolished at this dose. Replacement therapy can also be controlled by following the serum thyroxine concentration (measured by direct or indirect means) in the absence of the facilities for estimating serum TSH concentration.

It is a pleasure to acknowledge the support of the Wellcome Trust to D.E., of the Medical Research Council to D.E. and R.H., and the Scientific and Research Sub-committee of the Newcastle University Hospitals Group.

\section{References}

Bellabarba, D., Benard, B., and Langlois, M. (1972). Clinical Endocrinology,

Billewicz, W. Z., et al. (1969). Quarterly fournal of Medicine, 38, 255.

Block, W. D., Garrett, K. J., and Levine, J. B. (1966). Clinical Chemistry, 12,681

Braverman, L. E., Ingbar, S. H., and Sterling, K. (1970). Fournal of Clinical Investigation, 49,855 .

Clark, F., and Brown, H. J. (1970 a). British Medical fournal, 1, 713.

Clark, F., and Brown, H. J. (1970 b). British Medical fournal, 2, 543

Cotton, G. E., Gorman, C. A., and Mayberry, W. E. (1971). New England Fournal of Medicine, 285, 529.

Evered, D. C., and Hall, R. (1972). British Medical fournal, 1, 290.

Evered, D. C., Ormston, B. J., Smith, P. A., Hall, R., and Bird, T. (1973). British Medical fournal, $1,657$.

Fletcher, M. J. (1968). Clinica Chimica Acta, 22, 393 Goolden, A. W. G., Bateman, D., and Torr, S. (1971). British Medical

Hall, R., Anderson, J., and Smart, G. A. (1969). In Fundamentals of Clinical Endocrinology, p. 83. London, Pitman Medical.

Hall, R., Amos, J., and Ormston, B. J. (1971). British Medical fournal, 1, 582. Hesch, R.-D. and Evered, D. C. (1973). British Medical fournal, 1, 645.

Ingbar, S. H., and Woeber, K. A. (1968). In Textbook of Endocrinology, ed. R. H. Williams, 4th edn., p. 253. Philadelphia, Saunders.

Larsen, P. R. (1972). Metabolism, 21, 1073.

Means, J. H., DeGroot, L. J., and Stanbury, J. B. (1963). In The Thyroid and its Diseases. 3rd edn., p. 334. New York, McGraw Hill

Ormston, B. J., Garry, R., Cryer, R. J., Besser, G. M., and Hall, R. (1971). Lancet, 2, 10.

Pittman, C. S., Chambers, J. B., and Read, V. H. (1971). Fournal of Clinical Investigation, 50, 1187.

Selenkow, H. A., and Ingbar, S. H. (1970). In Harrison's Principles of Internal Medicine, ed. M. M. Wintrobe, et al., 6th edn., p. 456. New Ynternal Medicine, ed.

Stanbury, J. B. (1967). In Cecil-Loeb Textbook of Medicine, ed. P. B. Beeson and W. McDermott, 12th edn., p. 1299. Philadelphia, Saunders.

Sterling, K., Brenner, M. A., and Newman, E. S. (1970). Science, 169, 1099.

Strong, J. A. (1968). In Principles and Practice of Medicine, ed. Sir S. Davidson, 9th edn., p. 709. Edinburgh, Livingstone.

Taylor, S., Kapur, M., and Adie, R. (1970). British Medical fournal, 2, 270. 